F. Reprod. Fert. (1974) 38, 177-179

\title{
BIRTH OF LAMBS AFTER CULTURE OF SHEEP OVA IN VITRO FOR UP TO 6 DAYS
}

\author{
H. R. TERVIT AND L. E. A. ROWSON \\ A.R.C. Unit of Reproductive Physiology and Biochemistry, \\ 307 Huntingdon Road, Cambridge CB3 0JQ
}

(Received 29th August 1973)

Early cleavage stage (one-cell to eight-cell) sheep ova cultured by Tervit, Whittingham \& Rowson (1972) in a synthetic oviduct fluid medium (SOF) with an atmosphere of $5 \% \mathrm{CO}_{2} / 5 \% \mathrm{O}_{2} / 90 \% \mathrm{~N}_{2}$ cleaved readily during culture and twelve ova, which had been cultured for 3 to 6 days, developed to viable Day-13 or Day-14 conceptuses in recipient animals. Similar cleavage-stage ova had previously been reported to undergo only limited development during culture (Wintenberger, Dauzier \& Thibault, 1953; Hancock, 1963; Kraemer, 1966; Tervit \& McDonald, 1969; Moore, 1970; Moor \& Cragle, 1971; Moore \& Spry, 1972) and to be viable after culture for 1 or 2 days (Hancock, 1963; Tervit \& McDonald, 1969; Moore, 1970; Schwartz \& Ulberg, 1972; Schwartz, Thompson, Goode \& Ulberg, 1972). This communication describes the birth of lambs after the culture of early cleavage-stage ova for up to 6 days.

Welsh Mountain ewes were induced to superovulate and were mated at the ensuing oestrus. They were subjected to laparotomy 48 to $72 \mathrm{hr}$ after the onset of oestrus and the ova were flushed from the reproductive tract in a modified ('Tervit et al., 1972) Dulbecco's phosphate-buffered salt solution (PBS). The ova were held at $37^{\circ} \mathrm{C}$ in this medium until they were to be placed in culture, when they were removed from the PBS and washed in $2 \mathrm{ml} \mathrm{SOF}$ which had been previously gassed with a mixture of $5 \% \mathrm{CO}_{2} / 5 \% \mathrm{O}_{2} / 90 \% \mathrm{~N}_{2}$. The ova were then cultured in this atmosphere for up to 6 days in SOF, using the test-tube technique described previously (Tervit et al., 1972). After culture, the tubes were gently agitated, uncorked and the ova and medium were removed with a Pasteur pipette. The ova were isolated, examined for cleavage stage and were then placed into dishes containing PBS at $37^{\circ} \mathrm{C}$ and stored until transfer. At transfer, recipients were chosen whose stage of the oestrous cycle was approximately synchronous, i.e. from $12 \mathrm{hr}$ more advanced to $48 \mathrm{hr}$ less advanced, with the stage of development of the ova. Most recipients received two ova, one being transferred to each uterine horn.

The development and viability of the various cleavage-stage ova cultured in SOF are presented in Table 1. The ova recovered from the culture tubes were usually retarded compared to ova developing in vivo for the same length of time (Rowson \& Moor, 1966). Except for the eight-cell ova, increased culture length tended to be associated with the recovery of embryos which were increasingly retarded compared with ova developing in vivo. These effects are similar to those reported in the mouse (Bowman \& McLaren, 1970). Of the eighteen 


\begin{tabular}{|c|c|c|}
\hline \multicolumn{2}{|c|}{ 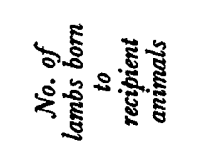 } & -0 -음 은 \\
\hline \multirow{6}{*}{ 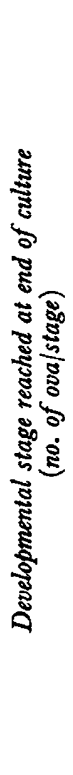 } & 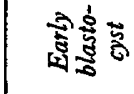 & $1111^{+} 100$ \\
\hline & 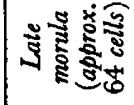 & $1-101+\pi$ \\
\hline & 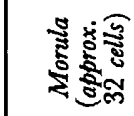 & $|\infty+ \pm| 01$ \\
\hline & 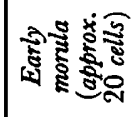 & $1+1=1+1$ \\
\hline & క్ర & ール $|1| 1$ \\
\hline & $\begin{array}{c}\widetilde{\widetilde{\Xi}} \\
\stackrel{\Xi}{\Xi}\end{array}$ & $\therefore 1|1| 1 \mid$ \\
\hline \multicolumn{2}{|c|}{ 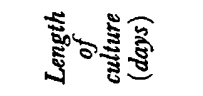 } & nom m nt \\
\hline \multicolumn{2}{|c|}{ 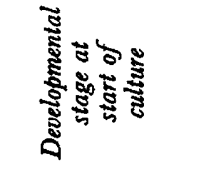 } & 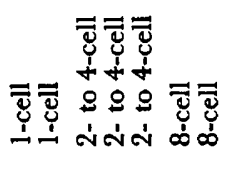 \\
\hline \multicolumn{2}{|c|}{ 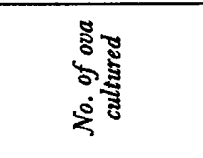 } & $0 N \omega N^{+} \Phi^{+}$ \\
\hline
\end{tabular}


eight-cell ova transferred after culture for 3 days, ten (56\%) survived to term. Moor \& Cragle (1971) are the only other workers who have cultured eight-cell ova for 3 days and then transferred the ova to recipients. They reported that none of fifteen ova cultured in enriched TCM-199 survived after transfer. The four eight-cell ova cultured for 4 days in SOF produced proportionately fewer lambs than the ova cultured for 3 days. The two- to four-cell ova cultured for 5 or 6 days cleaved readily during culture and $37 \%(10 / 27)$ and $25 \%(1 / 4)$, respectively, of the ova survived to term. The one-cell ova cultured for 6 days also cleaved readily but none $(0 / 17)$ survived to term. The lower viability of the two- to four-cell ova and lack of viability of the one-cell ova, relative to eight-cell ova cultured for 3 days, may have been due to the increased length of culture and not to the cleavage stage at commencement of culture. It was noted, however, that the six one-cell and six two- to four-cell ova cultured for 3 days also showed poor viability in the recipient animals.

Of the twenty-five lambs born, twenty-two $(88 \%)$ were alive after birth and three $(12 \%)$ died during difficult births. The three dead lambs were found to be anatomically normal and the twenty-two live lambs are healthy and are now between 3 and 7 months of age.

The results show that early cleavage-stage sheep ova are viable after culture for up to 6 days in a synthetic oviduct fluid medium and a gas phase containing $5 \%$ oxygen. This successful culture system can now be used to study aspects of embryo development and manipulation and for the transport of ova from country to country.

The assistance of Dr D. G. Whittingham in preparing a batch of medium is acknowledged. One of us (H.R.T.) is the recipient of a New Zealand Department of Scientific and Industrial Research Fellowship.

\section{REFERENCES}

Bowman, P. \& McLaren, A. (1970) Cleavage rate of mouse embryos in vivo and in vitro. F. Embryol. exp. Morph. 24, 203.

Hancock, J. L. (1963) Survival in vitro of sheep eggs. Anim. Prod. 5, 237.

Kraemer, D. C. (1966) In vitro fertilisation and culture of ovine ova. Diss. Abstr. 27, 285.

Moor, R. M. \& CRAGLe, R. G. (1971) The sheep egg: enzymatic removal of the zona pellucida and culture of eggs in vitro. 7. Reprod. Fert. 26, 401.

Moore, N. W. (1970) Preliminary studies on in vitro culture of fertilised sheep ova. Aust. F. biol. Sci. 23, 721 .

Moore, N. W. \& SPRy, G. A. (1972) The culture of fertilized sheep ova. 7. Reprod. Fert. 28, 139.

Rowson, L. E. A. \& Moor, R. M. (1966) Development of the sheep conceptus during the first fourteen days. F. Anat. 100, 777.

Schwartz, F. L., Thompson, L. H., Goode, L. \& Ulberg, L. C. (1972) Viability of sheep embryos cultured in oviduct fluid collected via cannula. F. Anim. Sci. 35, 254.

Schwartz, F. L. \& Ulberg, L. C. (1971) Viability of sheep embryos after culture. F. Anim. Sci. 35, 254.

Tervit, H. R. \& MCDonald, M. F. (1969) Culture and transplantation of sheep ova. $\mathcal{N}$.Z. $\mathcal{F l}$ agric. Res. 12, 313.

Tervit, H. R., Whittingham, D. G. \& Rowson, L. E. A. (1972) Successful culture in vitro of sheep and cattle ova. 7. Reprod. Fert. 30, 493.

Wintenberger, S., Dauzier, L. \& Thibault, G. (1953) Le développement in vitro de l'oeuf de la brebis et de celui de la chèvre. C.r. Séanc. Soc. Biol. 147, 1971. 